\begin{tabular}{c}
\hline Review of \\
ECONOMICS \\
and \\
INSTITUTIONS
\end{tabular}

\title{
Has the Euro Boosted Intra-Euro Area Exports? Evidence from Industry Data
}

\author{
Gavin Murphy \\ ESRI and Trinity College Dublin
}

\author{
Iulia Siedschlag \\ ESRI and Trinity College Dublin
}

\begin{abstract}
We estimate the euro effect on export patterns using a panel of industry data from Ireland over the period 1993-2004. Our main innovation is to account for country and industry-specific omitted trending variables bias. We find that the euro effect on Irish exports to the euro area countries relative to the rest of the trading partners of Ireland has been positive, significant and increasing since 2000. Furthermore, we find heterogeneous euro effects across industries. We find consistent significant positive euro effects for industries characterised by increasing returns to scale.
\end{abstract}

JEL classification: F33, F36, F41

Keywords: European economic and monetary union, gravity models, time and industry heterogeneity, omitted trending variables bias

We thank Patrick Honohan, John Fitz Gerald, Frances Ruane, participants at research presentations at the Economic and Social Research Institute in Dublin, the Irish Economics Association Conference in Westport, the EUROFRAME Conference in Dublin, the Editor, Francesco Venturini and an anonymous referee for helpful comments and suggestions. We also thank Bettina Drepper for her valuable assistance with the data collection and preparation for this analysis.

$\square$ Corresponding author. Economic and Social Research Institute, Whitaker Square, Sir John Rogerson's Quay, Dublin 2, Ireland. (Phone: +353 1863 2116, Fax: ; +353 1863 2100; Email: iulia.siedschlag@esri.ie)

\section{Recommended Citation}

Murphy, G., \& Siedschlag, I. (2011). Has the Euro Boosted Intra-Euro Area Exports? Evidence from Industry Data. Review of Economics and Institutions, 2 (3), Article 4. doi: 10.5202/rei.v2i3.44. Retrieved from http://www.rei.unipg.it/rei/article/view/44 


\section{Introduction}

In this paper we estimate the effect of the euro on export patterns. Specifically, we estimate an augmented gravity model using industry-level data on Irish exports over the period 1993-2004. We extend the literature on the effects of the euro on trade in two aspects. First, we provide empirical evidence about time and industry heterogeneity of the euro effects on trade. Second, we estimate an improved econometric model and account for unobserved country heterogeneity of the trading partners of Ireland and correct for country and industry-specific omitted trending variable bias.

The case of Ireland in the context of the euro effects on trade is interesting for two reasons. First, the trade openness measured as the volume of exports and imports as percent of gross domestic product (GDP) is one the highest in the euro area (150 percent of GDP in 2008 ${ }^{1}$. Second, in comparison to other euro area countries, trade with countries outside the euro area and outside the European Union accounts for a large share of the Irish trade.

In comparison to their level before the adoption of the single currency, total Irish exports in constant prices were higher by 83.9 percent in 2004. While Irish exports to the euro area countries were higher by 92.8 percent, exports to the European countries which were not in the euro area ${ }^{2}$ were only 45.5 percent higher. Exports from Ireland to non-euro area countries were higher by 91.6 percent.

This summary of export performance raises three research questions which we ask in this paper:

1. Has the single currency boosted Irish exports to euro area countries relative to exports to the rest of its trading partners?

2. Has the euro effect on exports changed over time?

3. Has the euro effect on exports varied across industries?

These questions are interesting and policy relevant for at least three reasons. First, the existing literature on the effect of the euro on trade patterns is inconclusive. The average effect of the euro on the trade among euro area countries found in existing studies ranges from 5 percent to 40 percent. ${ }^{3}$ Second, initial conditions and structural characteristics differentials are likely to result in country, industry and time-specific effects. These differential effects can be best captured with industry-level country studies using panel data as opposed to cross-country analysis. Third, the anticipated trade gains following the adoption of the single currency is an important input for the

\footnotetext{
1 Total exports and imports of goods and services as percent of GDP at current prices.

2 Denmark, Sweden, United Kingdom, Norway, Iceland, Switzerland, the Czech Republic, Hungary, Poland, the Slovak Republic.

3 Bun and Klaassen (2007) discuss recent studies on the euro effect on trade.
} 
decision about the time to enter the Third Stage of the European Economic and Monetary Union (EMU). This is relevant in the case of the EMU members with a derogation from adopting the single currency.

Our results indicate that the euro effect on Irish exports to the euro area countries relative to the rest of the trading partners of Ireland has been positive, significant and increasing since 2000. Furthermore, we find heterogeneous euro effects across industries. We find consistent significant positive euro effects for industries characterised by increasing returns to scale.

The remainder of this paper is structured as follows. Section 1 discusses the theoretical and empirical background for our analysis. In Section 2 we describe our data set and summary statistics. In Section 3 we explain our empirical strategy and model specifications. We discuss our estimation results in Section 4. Finally, Section 5 summarises our findings and concludes.

\section{Theoretical and Empirical Background}

Existing theory suggests several channels underlying a permanent structural break in bilateral trade following the adoption of a common currency: ${ }^{4}$ First, the elimination of exchange rate uncertainty is equivalent to a reduction of the risk related to trade which in turn is expected to boost trade. Second, the elimination of transaction costs related to operations in different currencies is likely to lead to an increased volume of trade. Third, increased price transparency fosters competition among firms and leads to a fall in the mark-up which in turn is expected to increase the volume of bilateral trade. Fourth, the single currency enables the euro area countries to better hedge against the exchange rate risk in their trade with non-euro area countries. This suggests that the single currency might also boost trade with countries outside the euro area.

Baldwin et al. (2005) propose a micro-founded theoretical model to explain the euro effect on bilateral trade. They suggest that the effect of the euro on trade is likely to vary across industries. This follows from the fact that the effect of exchange rate uncertainty on trade depends on the marginal cost faced by exporting firms and the cost structure of firms and firm's structure vary across industries. Their point of departure is the theoretical model of trade and firm heterogeneity proposed by Melitz (2003). The basic ingredients of this model are imperfect competition, the presence of fixed costs for market entry which exporting firms are facing and marginal cost differentials across firms. The main outcome of the model is that exporting is profitable only for firms with low marginal costs. It follows that industries with imperfect competition and increasing returns to scale are likely to benefit more from the adoption of the single currency.

The intuition in Baldwin et al. (2005) is that the elimination of the ex-

4 For a detailed discussion of the channels underlying the euro effect on bilateral trade see Micco et al. (2003) and Baldwin (2006a). 
change rate uncertainty leads to an increased export activity due to two effects: a) an increase in the volume of sales by existing exporters (intensive margin); b) a larger number of exporters (extensive margin).

The empirical literature on the effect of currency unions on trade has been initiated by Rose (2000). He finds that bilateral trade among countries belonging to currency unions is three-times higher in comparison to other trading partners after controlling for other trade determinants such as GDP and bilateral distance. The Rose methodology has several shortcomings which have been discussed extensively in the follow up literature. 5 Subsequent studies have used improved methodologies and have found smaller effects of currency unions on trade.

The interesting question in relation to EMU is whether the single currency is likely to foster trade integration among participating countries. Micco et al. (2003) was the first contribution to the literature focused on the EMU. They use panel data and analyse the dynamics of the impact of the euro on trade patterns. They find that the euro has fostered further trade integration among the euro area countries and this positive effect has increased over time ranging from 4 to 16 percent. They used a data set over the period 1993-2002 to uncover underlying changes in trade patterns due to the single currency. The main issue is to distinguish the effect of the euro from other factors driving trade integration such as the Single Market Programme.

De Nardis and Vicarelli (2003) extend the econometric framework to disentangle the EMU effect per se on trade from the trade effect due to eliminating exchange rate volatility and economic integration. They estimate a dynamic panel model using data over the period 1980-2000 and find that the short-run euro effect on trade ranges from 9 to 10 percent and the long-run effect from 16 to 19 percent.

Faruqee (2004) finds that initial conditions and structural characteristics have led to country-specific effects of the euro on countries' trade performance. Cross-country differences are explained by trade openness (more open economies are likely to benefit more); trade patterns (countries with higher intra-trade shares are likely to benefit more), exchange rate volatility (countries with greater exchange rate volatility are likely to benefit more), countries with more flexible product and labour markets are likely to benefit more. While the three largest countries have experienced trade gains similar to the euro area average, trade gains in the small countries have been more dispersed. Trade gains were greater than the euro area average in Spain, the Netherlands, Austria, and Belgium. Trade gains were lower than the euro area average in Portugal, Finland, and Ireland. Growth in the trade of Ireland with countries outside the euro area has outperformed the growth in trade of other countries with non-euro area countries.

Bun and Klaassen (2007) extend the standard gravity model that has

5 See for example Persson (2001), Tenreyro (2001) and Baldwin (2006b). 
been used to estimate the euro effect on trade by adding a time trend variable which varies across country-pairs. Their results point to a much lower euro effect on trade, 3 percent. In addition, they find that the magnitude of the bias due to omitted trending variables depends on the length of the sample with longer samples producing more precise estimates.

In contrast with most existing studies which estimate gravity models to analyse the euro effects on trade, Chintrakarn (2008) employs semi-parametric methods based on matching to account for self-selection issues and assumption about functional forms. Using a panel data of bilateral trade flows between 22 developed countries over 1994-2002, he finds that the euro has boosted intra-euro trade by 9 to 14 percent.

Flam and Nordström (2003) estimate euro effects on exports using data for nine industries (one digit, SITC classification) over the period 1989-2002. They estimate aggregate and industry-specific euro effects and find that, after controlling for other determinants of bilateral exports, the euro has fostered the level of trade between the euro countries by 15 percent and the level of trade with countries outside the euro area by 8 percent. The positive euro effect on trade has increased over time. In addition, they estimate industry-specific euro effects and find that the strongest effects were concentrated in industries with differentiated products with vertical specialisation across countries such as Beverages and tobacco; Chemicals and related products; Manufactured goods classified by material.

Baldwin et al. (2005) estimate industry-specific euro effects (two digit, and three digit ISIC Rev.3 classification) and find that the strongest euro effects have appeared in industries characterised by imperfect competition and increasing returns to scale such as Office, accounting and computing machinery; Motor vehicles, trailers and semi-trailers; Non-pharmaceutical chemicals; Chemical, rubber, plastics and fuel products; Electricity, gas, and water supply; and Building and repairing of ships and boats.

In the case of Ireland, Dwane et al. (2010) use aggregate trade data for Ireland and 21 major trading partners over the period 1950-2004 to estimate the effects of currency unions on Irish trade patterns. They find no significant euro effect on Irish trade.

With respect to empirical methodology, these papers estimate gravity models of bilateral trade flows where a dummy variable for countries which adopted the euro is added to the usual explanatory variables. Although the gravity model has been used extensively in the empirical trade literature, there are a number of methodological issues which have been discussed and need to be accounted for.

Anderson and van Wincoop (2003) point out that while the estimated gravity models are successful at explaining to a large extent bilateral trade flows, they are not theoretically founded. They demonstrate that a theorybased gravity equation needs to account for the dependence of trade flows on what they call bilateral and multilateral resistance. However, these terms 
are not observables and they propose to estimate them as a function of observable parameters. Given the difficulties of the proposed procedure and the required assumptions, they also estimate the gravity model by replacing the multilateral resistance terms by country-specific dummies, following Hummels (1999). The obtained model parameters are consistent.

Baldwin and Taglioni (2007) discuss extensively three typical mistakes in empirical studies which they call the golden, silver and bronze medal errors. The golden error stems from omitted variables bias, in particular unobserved trade-enhancing variables which are correlated with the common currency variable. The resulting upward bias can be eliminated by including time-invariant country dummies in cross-section data, time-invariant country and pairs dummies as well as time-varying country dummies. The silver medal mistake stems from incorrectly averaging bilateral trade flows. Specifically, the geometric average (sum of logs of trade flows) should be taken rather than the arithmetic average (log of the sum of trade flows). This bias can be offset by including country dummies. Finally the bronze medal arises when trade and GDP data available in US dollars are deflated by using US GDP deflators. This bias can be offset by including time dummies.

Santos Silva and Tenreyro (2006) suggest that in the presence of heteroskedastic errors, log-linearized models estimated by OLS such as the traditional gravity specifications, lead to inconsistent estimates. To obtain consistent estimates, they propose a Poisson pseudo-maximum-likelihood method and show that this is robust to different patterns of heteroskedasticity.

Our analysis relates to Flams and Nordström (2003) and Baldwin et al. (2005). We focus on industry-specific euro effects on the export patterns in Ireland. In comparison to these two contributions, our innovation is to estimate an improved econometric model to account for country and industryspecific time-varying omitted variables. Furthermore, we go beyond Dwane et al. (2010) by estimating not only aggregate average euro trade effects but also time and industry-specific trade effects.

\section{Data}

We use a panel of annual data on export flows between Ireland and its main trading partners across 21 industries over the period 1993-2004. We focus in particular on Irish exports to 28 OECD countries.6 Ireland exported on average approximately 90 percent of its total exports to this set of advanced economies ${ }^{7}$ over the analysed period. Our motivation for choosing the aforementioned period is as a result of the change in the collection of

\footnotetext{
6 The list of countries is given in Table A1 in the Appendix.

7 Using a sample of countries with similar levels of economic development reduces the unobserved heterogeneity in the sample. On this point, see also Baldwin (2006b).
} 
intra-EU trade statistics in 1993 and the implications for data comparability discussed in Baldwin (2006b) 8 The panel data is balanced and we have 588 observations per each industry.

The data on exports are taken from the OECD bilateral trade database. Trade flows are expressed in nominal US dollars, which we convert into Irish pounds using the annual average exchange rates..$^{9}$ We convert the data series into constant prices using the Irish export goods price index $(2000=100)$ taken from the European Commission's AMECO database.

Figure 1 shows the evolution of Irish exports in constant prices to the euro area countries and to the non-euro area countries.

Figure 1 - Irish Exports (Constant Prices) by Country Group Destination, 1993-2004

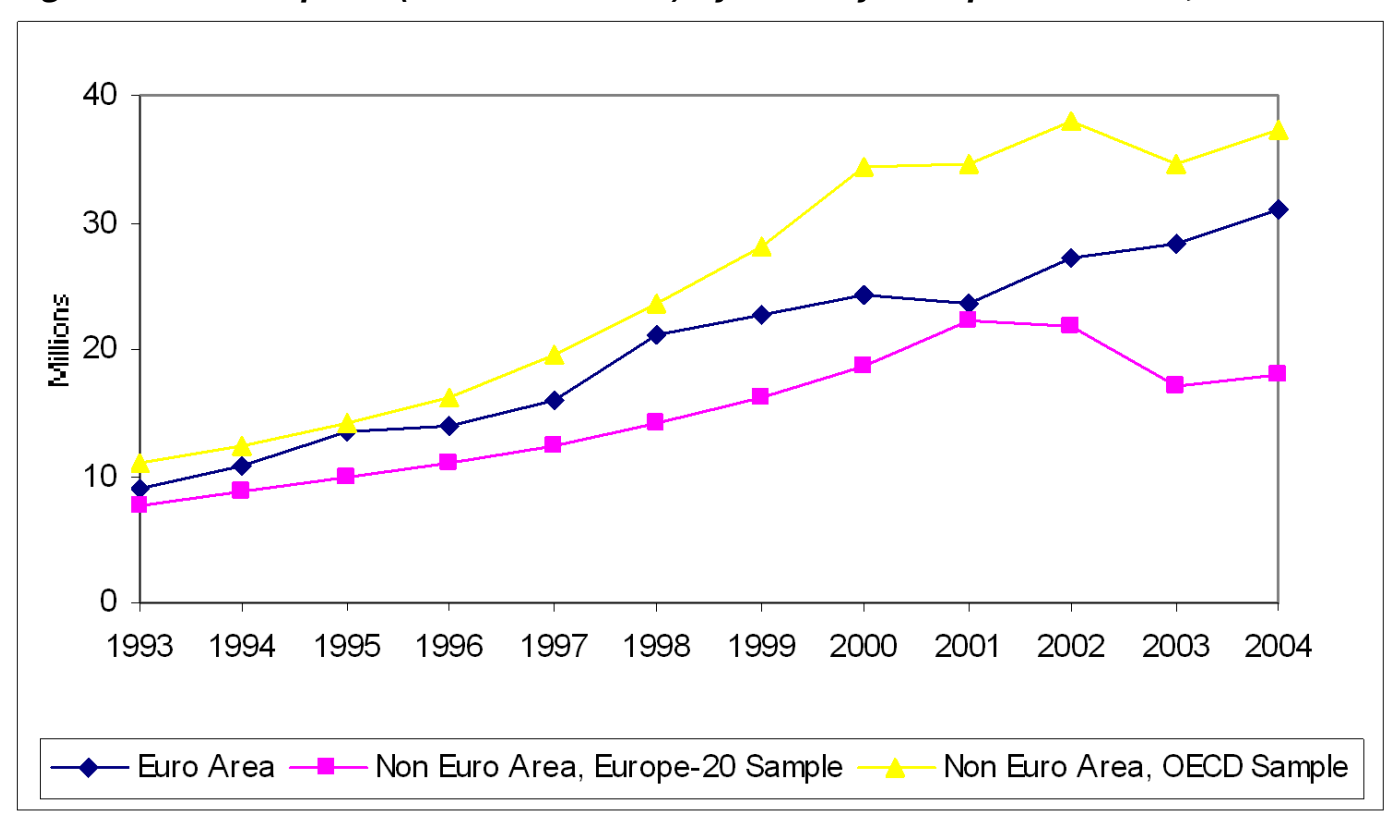

Source: Own calculations based on data from the OECD bilateral trade database.

In comparison to their level in 1997 - before the adoption of the single currency - total Irish exports in constant prices were higher by 83.9 percent in 2004. While Irish exports to the euro area countries were higher by 92.8 percent, exports to the European countries which are not in the euro area ${ }^{10}$ were only 45.5 percent higher. Exports from Ireland to non-euro area countries in the full OECD sample were higher by 91.6 percent.

8 From 1993 onwards, statistics on intra-EU trade have been collected by VAT authorities instead of customs offices. Baldwin (2006b) suggests that due VAT fraud data on intraEU trade statistics collected in this way might not be comparable with the trade statistics collected before this change.

9 The annual average exchange rate is calculated as an average of the average monthly exchange rate in each year taken from the Economic and Social Research Institute (ESRI) databank.

10 Denmark, Sweden, United Kingdom, Norway, Iceland, Switzerland, the Czech Republic, Hungary, Poland, the Slovak Republic. 
Detailed definitions of variables and data sources are given in Table A2 in the Appendix. Tables A3-A5 show summary statistics of the main variables. We consider two distinct groups of trading partners: the full sample of 28 OECD countries; and the subgroup of 20 European countries (Europe20) 11

On average, Irish real exports were slightly larger in the Europe-20 sample compared to the OECD sample, while real GDP in partner countries was on average larger in the OECD sample compared to the Europe-20 sample. Over the analysed period, average Irish real exports have been increasing in both samples. With respect to industry-specific exports, the largest average real exports were recorded in Pharmaceuticals, Chemicals (excluding Pharmaceuticals), and Office, accounting and computing machinery while the lowest average real exports were in Iron and steel; Scrap metal; Electricity, gas and water supply.

\section{Empirical Methodology and Econometric Issues}

We first estimate the aggregate effect of the euro on Irish exports to the euro area countries relative to the other trading partners. Second, we estimate time-specific euro effects on exports patterns. Third, we identify average industry-specific euro effects.

\subsection{Has the Euro Boosted Irish Exports to the Euro Area Coun- tries Relative to Exports to the Other Trading Partners?}

Our baseline model specification is an augmented gravity equation that explains Ireland's exports flows as a function of the GDP of the trading partner country (a proxy of import demand in the partner country), total industry exports (a proxy for the supply capacity of Irish industries), country, industry and time fixed effects. In addition, we control for omitted trending variables specific to the pairs between Ireland and its trading partners, as suggested by Bun and Klaassens (2007) and Baldwin and Taglioni (2007). As pointed out by Baldwin and Taglioni (2007), these time-varying country dummies eliminate the bias arising from the omission of the multilateral trade resistance term described by Anderson and Van Wincoop (2003). Further, our innovation is to control for industry-specific time-varying omitted variables by adding an interacted term obtained by interacting a trend variable $t\left(t=1993,1994, \ldots\right.$ 2004) with an industry dummy. $\square^{12}$

Our baseline gravity model specification is as follows:

\footnotetext{
11 The euro area countries (Austria, Belgium-Luxembourg, Finland, France, Germany, Greece, Italy, the Netherlands, Portugal, Spain), Denmark, Sweden, United Kingdom, the Czech Republic, Hungary, Iceland, Norway, Poland, the Slovak Republic, Switzerland.

12 The trend variable is a time index and it is equal to $1993,1994, \ldots 2004$.
} 


$$
\begin{aligned}
& \ln X_{k j t}^{I E}=\alpha_{0}+\alpha_{1} \ln \left(G D P_{j t}^{I E}\right)+\alpha_{2} \ln \left(T X_{k t}^{I E}\right)+\alpha_{3} E U R O_{j t}+\eta_{j}+\gamma_{k}+\lambda_{t}+ \\
& +\delta_{j} \times t+\phi_{k} \times t+\varepsilon_{k j t}
\end{aligned}
$$

The dependent variable $X_{k j t}^{I E}$ is the natural log of exports in constant prices from industry $\mathrm{k}$ in Ireland to country $j$ in year $t$. To account for zero export flows, in regressions we follow the approach proposed by Eichengreen and Irwin (1995) and use a transformed dependent variable obtained by adding one to export flows, $\ln \left(X_{k j t}^{I E}+1\right){ }^{13}$ The first explanatory variable, $\ln \left(G D P_{j t}^{I E}\right)$ is the natural $\log$ of the real gross domestic product in country $j$ in year $t$. The variable $\ln \left(T X_{k t}^{I E}\right)$ is the natural $\log$ of total Irish exports in industry $k$ in year $t$. The variable of interest is $\mathrm{EURO}_{j t}$, which is a binary variable equal to one from 1998 onwards for euro area countries and zero otherwise. ${ }^{14}$ It captures a permanent structural break in the volume of exports between Ireland and its euro country partners relative to the pre-euro period and relative to the volume of exports to other non-euro countries. If $\alpha_{3}>0$, this implies that the euro has led to an increase in the volume of exports from Ireland to its euro area country partners compared to the volume of exports during the pre-euro period and to the volume of exports to all other exporting partners included in the sample. $\eta_{j}$ controls for all time-invariant determinants of exports (e.g., bilateral distance) between Ireland and country $j . \gamma_{k}$ controls for all unobserved time-invariant industry characteristics that might affect industry exports. $\lambda_{t}$ captures time-specific common shocks to country-pair

13 This transformation of the dependent variable has been extensively used in estimating gravity models (see for example Baldwin and Di Nino, 2006; Calderón et al., 2007; Levy Yeyati et al. 2007; Stein and Duade, 2007). As pointed out by Eichengreen and Irwin (1995) and Baldwin and Di Nino (2006) this transformation of the dependent variable in gravity models has the advantage of simplicity and appears appropriate, in particular when trade values are large, since $\ln \left(1+\operatorname{Trade}_{i j}\right)$ is approximately equal to $\ln \left(\operatorname{Trade}_{i j}\right)$. For small trade values, $\ln \left(1+\right.$ Trade $\left._{i j}\right)$ is approximately equal to Trade $_{i j}$. However, given its ad hoc nature, if zero flows represent a significant part of the data, it could lead to biased estimates. In our data, zero export flows represent 11 per cent of observations. Alternative proposed methods to deal with zero trade values are discussed by Frankel (1997). These include dropping zero values (see for example Bikker, 1987; Rose, 2000) and using a Tobit estimator (see for example Biessen, 1991; Eaton and Tamura, 1994). Stein and Duade (2007) find that the estimates obtained with these alternative methods to deal with zero trade values are broadly similar. Santos Silva and Tenreyro (2006) propose a Poisson pseudo-maximumlikelihood (PPML) estimator to deal with zero trade flows and heteroskedasticity in gravity equations. We thank the referee for suggesting this reference to us. We have followed this suggestion and used a Poisson estimator to estimate our model specifications. However, given the large number of time-varying dummies we have encountered difficulties to obtain consistent estimates. We leave the use of this alternative method for an extension of our work.

14 Flam and Nordström (2003) show that the initial effects of the euro on exports can be identified in 1998. This is no unsurprising as uncertainty was removed in early 1998 as to which countries would enter into the euro along with the fixing of the national currency conversion rates to the euro. 
export determinants such as the state of the world economy ${ }_{15}^{15}$

To account for country-specific omitted trending variables we add to the model a trend variable $t(\mathrm{t}=1993,1994, \ldots, 2004)$ and interact it with a dummy for Ireland's trading partners $\delta_{j}$ to allow its coefficient to vary across countries. In addition, our innovation is to account for omitted trending variable bias across industries by interacting the trend variable $t$ with an industry dummy, $\phi_{k}$.

We estimate the above model using a fixed effect estimator. The estimation results are shown in Table 1.

\subsection{Has the Euro Effect on Exports Varied over Time?}

To estimate time-specific euro effects we add to the above baseline model interacted variables obtained by interacting the euro dummy and year dummies from 1999 onwards. The estimation results are shown in Table 2.

\subsection{Has the Euro Effect Been Homogeneous across Industries?}

To answer this question we add to our model specification a set of interacted variables obtained by interacting the euro dummy variable with a dummy variable, $I N D_{k}$, which is equal to one for industry $k$ and zero otherwise. This interaction variable captures the effect of the euro on exports in industry $k$ relative to the volume of exports in each industry during the preeuro period to the euro area and to the volume of exports in each industry to all other partner countries that are outside the euro area. The estimates for industry-specific aggregate average euro effects are shown in Table 3.

\subsection{Econometric Issues}

As pointed out by Bun and Klaassen (2007), as a result of entry and exit barriers due to sunk costs for example, past trade has an important influence on current trade. In other words, one would generally expect countries that trade with each other to continue trading with each other. It follows that the error terms may be serially correlated. Indeed, the Wooldridge test for no first order autocorrelation rejects the null of no first order correlation.

Second, the error terms may be correlated across panels. It is possible that a country shock may impact on all trade flows. The Peseran test rejects the null hypothesis that error terms are cross-sectionally independent.

To account for both serial correlation and cross-sectional dependency, we estimate Driscoll Kraay standard errors.

15 The fixed effects consist of country-industry pairs. 


\section{Empirical Results}

We estimate the baseline model discussed above using a fixed effect estimator for two distinct groups of trading partners: the full sample of 28 OECD countries; and the subgroup of 20 European countries (Europe-20). Our motivation for using the two different samples is to account for the possibility that the euro dummy might capture in part the effect of the Single Market Programme on the Irish exports to these European countries. Having implemented the Single Market Programme, all countries in the Europe20 sample receive thus the same "treatment".

\subsection{Aggregate Average Euro Effects}

Table 1 shows the estimates of our aggregate average euro effect. The estimated coefficient of the EURO dummy is not significantly different from zero. This result suggests that on average, ceteris paribus, the single currency has had no significant effect on the Irish exports to euro area countries relative to the rest of Ireland's trading partners in the sample. Similarly, for the European country sample we find that the euro effect on Irish export is insignificant. On average, the effect of the GDP of partner countries appears positive but not significant in all model specifications (see also Tables 2 and 3). This result reflects the fact that we control for multilateral resistance by using time-varying country-specific dummies. These time-varying countryspecific effects are significant in most cases. ${ }^{16}$ In contrast, the average effect of the industry supply capacity on Irish exports was positive and significant in all model specifications (see also Tables 2 and 3 )

Table 1 - Aggregate Average Euro Effects, Fixed Effects Estimates

\begin{tabular}{|c|c|c|c|c|}
\hline & \multicolumn{2}{|c|}{ OECD Sample } & \multicolumn{2}{|c|}{ Europe-20 Sample } \\
\hline & Coefficient & $\begin{array}{l}\text { Driscoll Kraay } \\
\text { Standard errors }\end{array}$ & Coefficient & $\begin{array}{c}\text { Driscoll Kraay } \\
\text { Standard errors }\end{array}$ \\
\hline Euro & -0.121 & $(0.135)$ & -0.120 & $(0.153)$ \\
\hline GDP & 1.050 & $(0.936)$ & 0.595 & $(1.467)$ \\
\hline $\operatorname{Ln}(T X)$ & $0.090 * * *$ & $(0.025)$ & $0.128 * * *$ & $(0.035)$ \\
\hline Obs. & \multicolumn{2}{|c|}{7056} & \multicolumn{2}{|r|}{5040} \\
\hline Obs. per group & \multicolumn{2}{|c|}{588} & \multicolumn{2}{|r|}{420} \\
\hline $\mathrm{R}^{2}$ & \multicolumn{2}{|c|}{0.175} & \multicolumn{2}{|r|}{0.208} \\
\hline
\end{tabular}

Notes: ${ }^{* * *}$ Significance at the $1 \%$ level, ${ }^{* *}$ significance at the $5 \%$ level, ${ }^{*}$ significance at the $10 \%$ level. The estimated models include country, industry and time-specific effects, as well as country- specific time trends, and sector-specific time trends. The estimated coefficients for these variables are available upon request from the authors.

16 These results are available from the authors upon requests. 


\subsection{Time-specific Euro Effects}

Figure 1 shows that the Irish exports to euro area countries have increased steadily since 2001. This suggests that the euro effect on Irish exports to the euro area countries might have been uneven across time. Thus, next we relax our assumption of a homogenous effect of the euro on exports over the period and estimate year-specific euro effects. Table 2 shows the estimated year-specific effects of the euro on Irish exports.

Table 2 - Aggregate Time Specific Euro Estimates, Fixed Effects Estimates

\begin{tabular}{|c|c|c|c|c|}
\hline & \multicolumn{2}{|c|}{ OECD Sample } & \multicolumn{2}{|c|}{ Europe-20 Sample } \\
\hline & Coefficient & $\begin{array}{c}\text { Driscoll Kraay } \\
\text { standard errors }\end{array}$ & Coefficient & $\begin{array}{c}\text { Driscoll Kraay } \\
\text { standard errors }\end{array}$ \\
\hline Euro*1998 & 0.072 & $(0.072)$ & 0.081 & $(0.086)$ \\
\hline Euro*1999 & 0.083 & $(0.089)$ & 0.143 & $(0.105)$ \\
\hline Euro*2000 & $0.213^{*}$ & $(0.111)$ & $0.305^{* *}$ & $(0.138)$ \\
\hline Euro*2001 & $0.246^{*}$ & $(0.131)$ & $0.438^{* *}$ & $(0.163)$ \\
\hline Euro*2002 & $0.358^{* *}$ & $(0.152)$ & $0.590 * * *$ & $(0.188)$ \\
\hline Euro*2003 & $0.494^{* * *}$ & $(0.174)$ & $0.705^{* * *}$ & $(0.213)$ \\
\hline Euro*2004 & $0.824 * * *$ & $(0.196)$ & $1.060 * * *$ & $(0.240)$ \\
\hline GDP & 1.090 & $(0.818)$ & 0.174 & $(1.271)$ \\
\hline $\ln (T X)$ & $0.090 * * *$ & $(0.025)$ & $0.129 * * *$ & $(0.035)$ \\
\hline Obs. & \multicolumn{2}{|c|}{7056} & \multicolumn{2}{|r|}{5040} \\
\hline Obs. per group & \multicolumn{2}{|c|}{588} & \multicolumn{2}{|r|}{420} \\
\hline $\mathrm{R}^{2}$ & \multicolumn{2}{|c|}{0.177} & \multicolumn{2}{|c|}{0.213} \\
\hline $\begin{array}{l}\text { Test of Joint } \\
\text { significance of time } \\
\text { specific euro effects }\end{array}$ & \multicolumn{2}{|c|}{$F(7,587)=2.99$, Prob $>F=0.0043$} & \multicolumn{2}{|c|}{$F(7,419)=2.81$, Prob $>F=0.0071$} \\
\hline
\end{tabular}

Notes: ${ }^{* * *}$ Significance at the $1 \%$ level, ${ }^{* *}$ significance at the $5 \%$ level, ${ }^{*}$ significance at the $10 \%$ level. The estimated models include country, industry and time-specific effects, as well as country- specific time trends, and sector-specific time trends. The estimated coefficients for these variables are available upon request from the authors.

As shown in column one of Table 2, the economic effect of the euro on exports to euro area countries relative to non-euro area countries appears positive and significantly different from zero since 2000 and it has increased over time. The significant year-specific economic effects ${ }^{17}$ range from 23.7 percent in 2000 to 128 percent in 2004.

The estimates obtained with the Europe-20 sample shown in column three of Table 2 are qualitatively similar. We find that the euro effect was not instant but appears to start in 2000 and has increased over time. When we compare the magnitude of the euro effect estimates across the samples we find they are slightly higher in the Europe-20 sample. This is partly due to the inclusion of the US in the benchmark group in the full sample. The US accounts for a large share of Irish exports which has risen rapidly from 8 percent of total Irish real exports in 1993 to just over 20 percent in 2004. The

17 The economic effect of the euro on the Irish exports is computed as follows: $\left(\exp ^{(\text {coefficient })}-1\right) * 100$. 
economic impact of the euro effect ranges from 35.6 percent in 2000 to 188.6 percent in 2004.

We reject the null that the time-specific euro effects are jointly equal to zero in both samples.

\subsection{Industry-specific Average Effects}

As discussed in Section 4.3, the analysis at the aggregate level may hide significant shifts in exporting activity at industry level arising from the adoption of the euro. We therefore further investigate whether or not the euro effect was heterogeneous across industries. Table 3 shows the industry-

Table 3 - Industry-specific Euro Effects, Fixed Effects Estimates

\begin{tabular}{|c|c|c|c|c|}
\hline \multirow[b]{2}{*}{ Industry } & \multicolumn{2}{|c|}{ OECD Sample } & \multicolumn{2}{|c|}{ Europe-20 Sample } \\
\hline & Coefficient & $\begin{array}{l}\text { Driscoll Kraay } \\
\text { standard errors }\end{array}$ & Coefficient & $\begin{array}{l}\text { Driscoll Kraay } \\
\text { standard errors }\end{array}$ \\
\hline Chemicals (excluding pharmaceuticals) & $0.304^{* * *}$ & $(0.086)$ & $0.235^{*}$ & $(0.127)$ \\
\hline Other non-metallic mineral products & $0.417 * *$ & (0.199) & 0.283 & $(0.218)$ \\
\hline Office, accounting and computing machinery & $0.258 * * *$ & $(0.095)$ & $0.267 * *$ & $(0.133)$ \\
\hline Radio, television and communication equipment & $0.321 * * *$ & $(0.108)$ & $0.419 * * *$ & $(0.135)$ \\
\hline Motor vehicles, trailers and semi-trailers & $-0.772 * *$ & $(0.316)$ & $-0.871 * *$ & $(0.346)$ \\
\hline Non-ferrous metals & $-0.500 * *$ & $(0.250)$ & $-0.556 * *$ & $(0.258)$ \\
\hline Rubber and plastics products & $-0.708 * * *$ & $(0.265)$ & $-0.916 * * *$ & $(0.323)$ \\
\hline Iron and steel & $-1.080^{*}$ & $(0.600)$ & -0.435 & $(0.457)$ \\
\hline Textiles, textile products, leather and footwear & $-0.313^{*}$ & $(0.178)$ & $-0.329 *$ & $(0.198)$ \\
\hline Wood and products of wood and cork & -0.424 & $(0.270)$ & $-0.688^{* *}$ & $(0.226)$ \\
\hline Agriculture, hunting, forestry and fishing & -0.025 & $(0.257)$ & -0.082 & $(0.259)$ \\
\hline Mining and quarrying & -0.138 & $(0.307)$ & 0.016 & $(0.314)$ \\
\hline Food products, beverages and tobacco & -0.050 & $(0.180)$ & -0.062 & $(0.220)$ \\
\hline Pulp, paper, paper products, printing and publishing & 0.087 & $(0.097)$ & 0.115 & $(0.185)$ \\
\hline Coke, refined petroleum products and nuclear fuel & -0.490 & $(0.360)$ & -0.23 & $(0.307)$ \\
\hline Pharmaceuticals & 0.150 & $(0.148)$ & -0.05 & $(0.145)$ \\
\hline $\begin{array}{l}\text { Fabricated metal products (except machinery and } \\
\text { equipment) }\end{array}$ & -0.144 & $(0.270)$ & -0.144 & $(0.282)$ \\
\hline Medical, precision and optical instruments & -0.188 & $(0.181)$ & -0.064 & $(0.205)$ \\
\hline Aircraft and spacecraft & -0.016 & $(0.329)$ & -0.149 & $(0.294)$ \\
\hline Electricity, gas and water supply & 0.244 & (0.199) & 0.283 & $(0.263)$ \\
\hline Scrap metal & 0.520 & $(0.505)$ & 0.412 & $(0.543)$ \\
\hline GDP & 1.050 & $(0.936)$ & 0.595 & 1.466 \\
\hline $\ln (T X)$ & $0.097 * * *$ & $(0.024)$ & $0.138^{* * *}$ & 0.034 \\
\hline Obs. & \multicolumn{2}{|c|}{7056} & \multicolumn{2}{|c|}{5040} \\
\hline Obs. per group & \multicolumn{2}{|c|}{588} & \multicolumn{2}{|r|}{420} \\
\hline$R^{2}$ & \multicolumn{2}{|c|}{0.183} & \multicolumn{2}{|c|}{0.213} \\
\hline $\begin{array}{l}\text { Test of Joint Significance of industry specific euro } \\
\text { effects }\end{array}$ & \multicolumn{2}{|c|}{$\begin{array}{l}F(21,587)=2.46, \text { Prob }>F \\
=0.0003\end{array}$} & \multicolumn{2}{|c|}{$\begin{array}{l}F(21,419)=2.04, \text { Prob }>F= \\
0.0047\end{array}$} \\
\hline
\end{tabular}

Notes: ${ }^{* *}$ Significance at the $1 \%$ level, ${ }^{* *}$ significance at the $5 \%$ level, ${ }^{*}$ significance at the $10 \%$ level. The estimated models include country, industry and time-specific effects, as well as country- specific time trends, and sector-specific time trends. The estimated coefficients for these variables are available upon request from the authors.

specific estimates of average euro effects for both samples. Based on the OECD sample we find a positive and significant euro effect on exports in Chemicals (excluding pharmaceuticals); Other non-metallic mineral products; Office, accounting and computing machinery; Radio, television and communication equipment. In a number of sectors, the coefficient on the 
Table 4 - Industry-specific Economic Effects of the Euro on Irish Exports

\begin{tabular}{lcc}
\hline \hline & OECD Sample & Europe-20 Sample \\
\hline Chemicals (excluding pharmaceuticals) & $34.99^{* * *}$ & $27.12^{*}$ \\
Other non-metallic mineral products & $52.20^{* *}$ & 32.31 \\
Office, accounting and computing machinery & $29.69^{* * *}$ & $31.00^{* *}$ \\
Radio, television and communication equipment & $37.71^{* * *}$ & $52.20^{* * *}$ \\
Motor vehicles, trailers and semi-trailers & $-53.70^{* *}$ & $-58.10^{* *}$ \\
Non-ferrous metals & $-39.35^{* *}$ & $-42.88^{* *}$ \\
Rubber and plastics products & $-50.84^{* * *}$ & $-60.15^{* * *}$ \\
Iron and steel & $-66.04^{*}$ & -35.60 \\
Textiles, textile products, leather and footwear & $-26.66^{*}$ & $-28.11^{*}$ \\
Wood and products of wood and cork & -34.30 & $-49.84^{* *}$ \\
Agriculture, hunting, forestry and fishing & -2.96 & -7.69 \\
Mining and quarrying & -13.06 & 2.02 \\
Food products, beverages and tobacco & -4.88 & -5.82 \\
Pulp, paper, paper products, printing and publishing & 9.42 & 12.75 \\
Coke, refined petroleum products and nuclear fuel & -38.74 & -20.55 \\
Pharmaceuticals & 16.18 & -4.88 \\
Fabricated metal products (except machinery and equipment) & -13.06 & -13.06 \\
Medical, precision and optical instruments & -17.30 & -5.82 \\
Aircraft and spacecraft & -1.98 & -13.93 \\
Electricity, gas and water supply & 27.12 & 32.31 \\
Scrap metal & 68.20 & 50.68 \\
\hline \hline
\end{tabular}

Notes: The economic effect of the euro on the Irish exports is computed as follows: (exp(coefficient) -1$)^{*} 100{ }^{* * *}$ Significance at the $1 \%$ level, ${ }^{* *}$ significance at the $5 \%$ level, ${ }^{*}$ significance at the $10 \%$ level.

euro dummy is negative and significant. Our findings suggest that the euro has led to higher exports to non-euro area countries relative to euro area countries in the following industries: Motor vehicles, trailers and semitrailers; Non-ferrous metals; Rubber and plastic products; Iron and steel; Textiles, textile products, leather and footwear. Our results suggest that in some industries the reduction of trade costs benefited goods that became more competitive in markets outside the euro area as well. This result is consistent with findings of Flam and Nordström (2003) and Baldwin et al. (2005).

When we compare these results to those based on the Europe-20 sample we notice that the single currency has boosted Irish exports to euro area countries in the same sectors except for Other non-metallic mineral products. In addition, we find that the euro has led to higher exports to noneuro area countries relative to euro area countries in Wood and products of wood and cork, while the effect of the euro on exports in the Iron and steel industry is no longer significant.

We reject the null that the industry-specific euro effects are jointly equal to zero in both samples.

The economic effects of the euro on Irish exports in each industry are shown in Table 4.

Focusing on the industries where the euro boosted Irish exports to euro area countries relative to non-euro area countries, we find that the effect ranges between 30 to 52 per cent. In those industries in which the euro 
boosted exports to non-euro area countries the effect ranges from 27 to 66 percent. Our econometric results indicate that the effect of the euro on Irish exports has differed across industries.

For the Europe-20 sample the economic effect of the euro on Irish exports ranges from 27 to 52 percent in those industries in which the euro boosted trade to euro area countries. In those industries in which the euro boosted exports to non-euro area countries the effect ranges from 28 to 60 percent.

Our results across the two samples are quite similar. As we control for the effect of the Single Market in the European sample this suggests that the potential bias in our euro estimates due to the Single Market is negligible in our OECD sample.

\subsection{What Explains the Industry-specific Euro Trade Effect?}

As discussed in Section 1, previous theoretical and empirical research on the impact of the euro on trade has shown that sectors characterized by imperfect competition and increasing returns to scale, are likely to benefit more from the adoption of the euro in comparison to the other industries.

We compare the industries in which we obtain statistically significant euro effects to the classification of manufacturing industries with scale economies suggested by Pratten (1988). Table A6 in the Appendix shows a ranking of industries after the size of economies of scale. We find that most of the industries for which we find a significant effect of the euro on Irish exports are characterised as moderately or substantially scale intensive.

These results are consistent with Flam and Nordström (2003) and Baldwin et al. (2005). It is likely that the reduction of transaction costs due to the single currency have benefited these industries. Furthermore, the reduction of trade costs benefited goods that became more competitive in markets outside the euro area as well.

\section{Conclusions}

We use a panel of cross-country industry data over the period 1993-2004 and estimate the euro effect on Irish exports to its trading partners. We estimate an augmented gravity panel model which allows us to control for unobserved country and industry heterogeneity. Our innovation is to account in addition for country and industry-specific omitted trending variables bias. We estimate average and time-specific aggregate effects as well as industry-specific euro effects.

Our results suggest that on average, ceteris paribus, the single currency has had no significant aggregate effect on the Irish exports to euro area countries relative to the rest of the Irish trading partners. This result is consistent with Dwane et al. (2010). However, when we relax the assumption of homogeneous euro effects over the analysed period, we find that the impact 
of the euro on exports to euro area countries relative to non-euro area countries was significant and positive from 2000 onwards and that this effect has increased over time.

Our industry-specific estimates indicate that the euro effects have been heterogeneous across industries. We find a positive and significant euro effect on exports in Chemicals (excluding pharmaceuticals); Other non-metallic mineral products; Office, accounting and computing machinery; Radio, television and communication equipment. We find that the euro has led to higher exports to the non-euro area countries relative to euro area countries in Iron and steel; Non-ferrous metals; Motor vehicles, trailers and semitrailers; Textiles, textile products, leather and footwear; Rubber and plastics products. The majority of these industries are characterised by increasing returns to scale. These results are consistent with Flam and Nordström (2003) and Baldwin et al. (2005). Furthermore, the reduction of trade costs benefited goods that became more competitive in markets outside the euro area as well.

Our empirical evidence on industry and time-specific trade gains from the single currency suggests the importance of going beyond the analysis of aggregate average effects of the euro on trade. 


\section{References}

Anderson, J.E., \& van Wincoop, E. (2003). Gravity with Gravitas: A Solution to the Border Puzzle. The American Economic Review 93(1), 170-192. doi:10.1257/000282803321455214

Baldwin R, Skudelny, F., \& Taglioni, D. (2005). Trade Effects of the Euroevidence from Sectoral Data. (Working Paper Series No. 446). Frankfurt: European Central Bank.

Baldwin, R. (2006a). In or Out: Does it Matter? An Evidence-Based Analysis of the Euro's Trade Effects. London: Centre for Economic Policy Research.

Baldwin, R. (2006b). The Euro's Trade Effects. (Working Paper Series No. 594). Frankfurt: European Central Bank.

Baldwin, R., \& Di Nino, V. (2006). Euros and Zeros: the Common Currency Effect on Trade in New Goods. (Discussion Papers 5973). London: Centre for Economic Policy Research.

Baldwin, R., \& Taglioni, D. (2007). Trade Effects of the Euro: A Comparison of Estimators. Journal of Economic Integration, 22(4), 780-818.

Biessen, G. (1991). Is the Impact of Central Planning on the Level of Foreign Trade Really Negative? Journal of Comparative Economics, 15(10), 22-44 doi:10.1016/0147-5967(91)90103-Z

Bikker, J. (1987). An International Trade Flow Model with Substitution: An Extension of the Gravity Model. Kyklos, 40(3), 315-337 doi:10.1111/j.1467-6435.1987.tb00683.x

Bun, M.J.G., \& Klaassen, F.J.G.M. (2007). The Euro Effect on Trade is Not as Large as Commonly Thought. Oxford Bulletin of Economics and Statistics, 69(4), 473-496 doi:10.1111/j.1468-0084.2007.00448.x

Calderón, C., Chong, A., Stein, E. (2007). Trade Intensity and Business Cycle Synchronization: Are Developing Countries Any Different? Journal of International Economics, 71(1), 2-21

doi:10.1016/j.jinteco.2006.06.001

Chintrakarn, P. (2008). Estimating the Euro Effects on Trade with Propensity Score Matching. Review of International Economics, 16(1), 186-198 doi:10.1111/j.1467-9396.2007.00725.x

de Nardis, S., \& Vicarelli, C. (2003). Currency Unions and Trade: The Special Case of EMU. Review of World Economics, 139(4), 625-649 doi:10.1007/BF02653107 
Dwane, C., Lane, P., \& McIndoe, T. (2010). Currency Unions and Irish External Trade. Applied Economics, 42(19), 2393-2397 doi:10.1080/00036840701858109

Eaton, J., Tamura, A. 1994. Bilaterism and Regionalism in Japanese and U.S. Trade and Direct Foreign Investment Patterns. Journal of the Japanese and International Economics, 8, 478-510.

Eichengreen, B., \& Irwin, D. (1995). Trade Blocs, Currency Blocs and the Reorientation of Trade in the 1930s. Journal of International Economics, 38(12), 1-24 doi:10.1016/0022-1996(95)92754-P

Faruqée, H. (2004). Measuring the Trade Effects of EMU. (Working Paper No. 04/154). Washington DC: International Monetary Fund.

Flam, H., \& Nordström, H. (2003). Trade Volume Effects of the Euro: Aggregate and Sector Estimates. (Seminar Paper No. 746). Stockholm: Institute for International Economic Studies, University Stockholm.

Frankel, J. (1997). Regional Trading Blocs in the World Economic System. Washington DC: Institute for International Economics.

Hummels, D. (1999). Toward a Geography of Trade Costs. Mimeo, University of Chicago.

Levy Yeyati, E., Panizza, U., \& Stein, E. (2007). The Cyclical Nature of NorthSouth FDI Flows. Journal of International Money and Finance, 26(1), 104-130. doi:10.1016/j.jimonfin.2006.10.012

Melitz, M. (2003). The Impact of Trade on Intra-industry Reallocations and Aggregate Industry Productivity. Econometrica, 71(6): 1695-1725 doi:DOI:10.1111/1468-0262.00467

Micco, A, Stein, E., \& Ordoñez, G. (2003). The Currency Union Effect on Trade: Early Evidence from EMU. Economic Policy, 18(37), 315-356 doi:DOI: 10.1111/1468-0327.00109_1

Persson, T. (2001). Currency Unions and Trade: How Large is the Treatment Effect? Economic Policy, [HTML]FFFF0016(33), 433-462 doi:10.1111/1468-0327.00081

Pratten, C. (1988). A Survey of the Economies of Scale. (Economic Papers No. 67). Brussels: Commission of the European Communities.

Rose, A. (2000). One Money, One Market: the Effect of Common Currencies on Trade. Economic Policy, 15(30), 9-45. doi:10.1111/1468-0327.00056

Santos Silva, J.M.C., \& Tenreyro, S. (2006). The Log of Gravity. The Review of Economics and Statistics, 88(4), 641-658. 
Stein, E., \& Duade, C. (2007). Longitude Matters: Time Zones and the Location of Foreign Direct Investment. Journal of International Economics, 71(1), 96-112. doi:10.1016/j.jinteco.2006.01.003

Tenreyro, S. (2001). On the causes and consequences of currency unions. Mimeo, Harvard University. 


\section{Appendix}

Table A1 - List of Countries

\begin{tabular}{ll}
\hline \hline Euro Area Countries & $\begin{array}{l}\text { Austria, Belgium-Luxembourg, Finland, France, Germany, Greece, } \\
\text { Italy, Netherlands, Portugal, Spain }\end{array}$ \\
\hline \multirow{3}{*}{ Non-Euro Area Countries } & Sweden, Denmark, United Kingdom, United States, Australia, \\
& Canada, Czech Republic, Hungary, Iceland, Japan, Korea, Mexico, \\
& New Zealand, Norway, Poland, Slovak Republic, Switzerland, Turkey \\
\hline \hline
\end{tabular}

Table A2 - Variables Definitions and Data Sources

\begin{tabular}{ll}
\hline \hline Variables & Definition and Source \\
\hline $\ln X_{k j t}^{I E}$ & $\begin{array}{l}\text { The natural log of Irish exports in constant prices from industry } k \text { to country j in year } \\
\text { t. We convert nominal exports expressed in thousands US dollars to Irish pounds } \\
\text { which we then deflate using the Irish export goods price index (2000=100). Sources: } \\
\text { OECD bilateral trade database and European Commission's AMECO database }\end{array}$ \\
\hline $\ln \left(G D P_{j t}^{I E}\right)$ & $\begin{array}{l}\text { The natural log of the real gross domestic product (constant } 2000 \text { US dollars) in } \\
\text { country j in year t. Source: World Development Indicators. }\end{array}$ \\
\hline $\ln \left(T X_{k t}^{I E}\right)$ & $\begin{array}{l}\text { The natural log of total real Irish exports in industry } k \text { in year t. Export flows equal to } \\
\text { zero were replaced with a value of } 1 \text { before the log transformation. Sources: OECD } \\
\text { bilateral trade database and European Commission's AMECO database }\end{array}$ \\
\hline$E U R O_{j t}$ & $\begin{array}{l}\text { Binary variable equal to one from } 1998 \text { onwards for euro area countries and zero } \\
\text { otherwise. }\end{array}$ \\
\hline \hline
\end{tabular}

Table A3 - Summary Statistics of Main Aggregated Variables, 1993-2004

\begin{tabular}{lcccc}
\hline \hline & \multicolumn{2}{c}{ OECD Sample } & \multicolumn{2}{c}{ Europe-20 Sample } \\
\cline { 2 - 5 } & Mean & $\begin{array}{c}\text { Standard } \\
\text { Deviation }\end{array}$ & Mean $\begin{array}{c}\text { Standard } \\
\text { Deviation }\end{array}$ \\
\hline log of industry real export flows to trading partners $(\operatorname{In}(X+1))$ & 7.14 & 3.83 & 7.35 & 3.84 \\
log of real GDP in partner countries & 26.28 & 1.53 & 25.94 & 1.37 \\
log of total real exports in each industry & 12.90 & 2.46 & 12.90 & 2.46 \\
\hline \hline
\end{tabular}

Sources: OECD bilateral trade database and European Commissionâs AMECO database. 
Table A4 - Summary Statistics of Irish Exports in Constant Prices by Year, 1993-2004

\begin{tabular}{ccccc}
\hline & \multicolumn{2}{c}{ OECD Sample } & \multicolumn{2}{c}{ Europe 20 Sample } \\
\cline { 2 - 5 } & Mean & Std Deviation & Mean & Std Deviation \\
\hline 1993 & 6.44 & 3.87 & 6.68 & 3.90 \\
1994 & 6.69 & 3.84 & 6.94 & 3.87 \\
1995 & 6.81 & 3.83 & 7.03 & 3.89 \\
1996 & 7.02 & 3.78 & 7.24 & 3.80 \\
1997 & 7.15 & 3.79 & 7.37 & 3.75 \\
1998 & 7.27 & 3.77 & 7.50 & 3.77 \\
1999 & 7.38 & 3.76 & 7.58 & 3.77 \\
2000 & 7.47 & 3.84 & 7.67 & 3.81 \\
2001 & 7.37 & 3.88 & 7.53 & 3.90 \\
2002 & 7.31 & 3.90 & 7.46 & 3.88 \\
2003 & 7.38 & 3.82 & 7.54 & 3.80 \\
2004 & 7.42 & 3.84 & 7.60 & 3.83 \\
\hline \hline
\end{tabular}

Sources: OECD bilateral trade database and European Commissionâs AMECO database.

Table A5 - Summary Statistics of Irish Exports in Constant Prices by Industry, 19932004

\begin{tabular}{lrrrr}
\hline \hline & \multicolumn{2}{c}{ OECD Sample } & \multicolumn{2}{c}{ Europe 20 Sample } \\
\cline { 2 - 5 } & Mean & $\begin{array}{r}\text { Standard } \\
\text { Deviation }\end{array}$ & Mean & $\begin{array}{c}\text { Standard } \\
\text { Deviation }\end{array}$ \\
\hline Agriculture, Hunting, Forestry And Fishing & 6.30 & 3.13 & 6.64 & 3.22 \\
Mining And Quarrying & 5.10 & 3.78 & 5.54 & 3.94 \\
\hline Food Products, Beverages And Tobacco & 10.41 & 1.85 & 10.49 & 2.04 \\
Textiles, Textile Products, Leather And Footwear & 8.17 & 2.07 & 8.37 & 2.15 \\
Wood And Products Of Wood And Cork & 5.59 & 2.86 & 6.28 & 2.64 \\
Pulp, Paper, Paper Products, Printing And & 10.03 & 1.83 & 10.45 & 1.74 \\
Publishing & & & & \\
Coke, Refined Petroleum Products And Nuclear & 3.85 & 3.50 & 4.24 & 3.58 \\
Fuel & & & & \\
Chemicals (Excluding Pharmaceuticals) & 11.07 & 2.13 & 11.04 & 2.23 \\
\hline Pharmaceuticals & 10.36 & 2.35 & 10.29 & 2.52 \\
Rubber And Plastics Products & 8.14 & 1.89 & 8.37 & 2.00 \\
Other Non-Metallic Mineral Products & 6.65 & 2.45 & 6.58 & 2.44 \\
Iron And Steel & 4.81 & 3.03 & 5.30 & 3.12 \\
Non-Ferrous Metals & 6.40 & 2.92 & 6.99 & 2.93 \\
Fabricated Metal Products (Except Machinery & 7.61 & 2.04 & 7.71 & 2.15 \\
And Equipment) & 11.22 & 2.01 & 11.45 & 1.99 \\
Office, Accounting And Computing Machinery & & 2.17 & 9.87 & 2.09 \\
Radio, Television And Communication Equipment & 9.80 & 2.09 & 9.33 & 2.15 \\
\hline Medical, Precision And Optical Instruments & 9.46 & 2.87 & 5.49 & 3.02 \\
Motor Vehicles, Trailers And Semi-Trailers & 5.26 & 2.66 & 6.58 & 2.65 \\
Aircraft And Spacecraft & 6.76 & 1.08 & 0.25 & 1.25 \\
\hline Electricity, Gas And Water Supply & 0.20 & 3.44 & 3.00 & 3.72 \\
\hline Scrap Metal & 2.81 & &
\end{tabular}

Sources: OECD bilateral trade database and European Commissionâs AMECO database. 
Table A6 - Manufacturing Industries Ranked by Size of Economies of Scale (EOS)

\begin{tabular}{ll}
\hline \hline Industry & Remarks \\
\hline Motor Vehicles & $\begin{array}{l}\text { Very substantial EOS in production and in } \\
\text { development } \\
\text { Variable EOS, very substantial in aircraft }\end{array}$ \\
$\begin{array}{l}\text { Other means of transport } \\
\text { Chemical industry }\end{array}$ & $\begin{array}{l}\text { Substantial EOS in production processes, in } \\
\text { some segments R\&D is an important source of } \\
\text { EOS }\end{array}$ \\
Man-made Fibres & Substantial EOS in general \\
Metals & Substantial EOS in general \\
Office machinery & Substantial EOS at product level \\
Mechanical engineering & Substantial production EOS \\
Electrical and instrument engineering & Substantial production EOS \\
Paper printing and publishing & Substantial EOS in paper mills and printing \\
Non-metallic mineral products & Substantial EOS \\
Metal articles; Rubber plastics; Drink and tobacco; & Moderate to small EOS \\
Food; Other manufacturing; Textile industry Timber & \\
and wood; Footwear and clothing; Leather and & \\
leather goods & \\
\hline \hline
\end{tabular}

Source: Pratten (1988) 